\title{
Article
}

\section{Developing a sense of place toolkit: Identifying destination uniqueness}

Jarratt, David, Phelan, Christopher James, Wain, Jenny and Dale, Sarah

Available at http://clok.uclan.ac.uk/22055/

Jarratt, David ORCID: 0000-0002-7244-428X, Phelan, Christopher James, Wain, Jenny and Dale, Sarah (2019) Developing a sense of place toolkit: Identifying destination uniqueness. Tourism and Hospitality Research, 19 (4). pp. 408421. ISSN 1467-3584

It is advisable to refer to the publisher's version if you intend to cite from the work. http://dx.doi.org/10.1177/1467358418768678

For more information about UCLan's research in this area go to http://www.uclan.ac.uk/researchgroups/ and search for <name of research Group>.

For information about Research generally at UCLan please go to http://www.uclan.ac.uk/research/

All outputs in CLoK are protected by Intellectual Property Rights law, including Copyright law. Copyright, IPR and Moral Rights for the works on this site are retained by the individual authors and/or other copyright owners. Terms and conditions for use of this material are defined in the policies page. 
This is an electronic copy (author's post-print) of an article published in Tourism and Hospitality Research (ISSN: 1467-3584, ESSN: 1742-9692). The journal is available at: http://journals.sagepub.com/home/thr The final published version is available at: http://dx.doi.org/10.1177/1467358418768678

\title{
Developing a sense of place toolkit: Identifying destination uniqueness
}

\author{
David Jarratt ${ }^{1}$, Chris Phelan ${ }^{2}$, Jenny Wain ${ }^{3}$ and Sarah Dale ${ }^{4}$ \\ Corresponding author: Dr David Jarratt djarratt@uclan.ac.uk
}

\begin{abstract}
It has long been recognised that the tangible and intangible characteristics that make a location distinctive and memorable, contribute significantly to destination image. How this destination feel is communicated, has largely been the domain of place branding and destination marketing, which have the potential to miss stakeholder voices. Recently though, practitioners are starting to carefully consider 'sense of place'; that is an emotional attachment to place, which is defined more carefully in the literature review of this article, and which corresponds with long-running academic discussions. This paper attempts to identify some of these and bridge the gap between academic theory on sense of place and practice. In the UK, many rural areas are now seeking to operationalise sense of place through toolkit documents that might inform landscape interpretation and destination branding. A scenario echoed internationally, where local distinctiveness features in both rural and urban planning. However, sense of place in a tourism context, and more specifically the development of these toolkits, has received limited academic attention. Hence, this paper presents the case of Morecambe Bay, and the development of a dedicated sense of place toolkit. The subsequent case emerges from a collaboration between academics and practitioners and draws on participant observation, semi-structured interviews and document analysis. Specifically, the paper outlines a series of workshop activities developed with destination stakeholders and identifies how these inform subsequent toolkit design. It offers a critical analysis of the benefits and potential pitfalls of employing this approach. This case is of value to academics and destination stakeholders interested in identifying and communicating the uniqueness and emotional tone of the destination.
\end{abstract} Key lessons and recommendations are identified for those engaging in similar toolkit development initiatives.

Keywords: Place; Sense of Place; Sense of Place Toolkit; Destination Marketing; Place Branding; Place Identity; Morecambe Bay; Rural Tourism; Tourism; Local Distinctiveness.

\footnotetext{
${ }^{1}$ University of Central Lancashire

${ }^{2}$ Edge Hill University

${ }^{3}$ Independent Consultant

${ }^{4}$ Nurture Lakeland
} 


\section{INTRODUCTION}

Place marketing and branding have become important strategic tools to allow destinations to create their own unique identity and to differentiate themselves from the competition. Indeed, it is now accepted, that nations, regions, and cities must project a positive brand image to facilitate inward investment and attract visitors, residents and businesses (Anholt, 2010; Baker and Cameron, 2008; Kotler and Gertner, 2015; Marzano and Scott, 2009; Pike, 2016; UNWTO, 2009). Morgan et al., (2011:12) advocate that this positive image and reputation must be communicated to residents and visitors through 'the emotional power of a destination's tone'. With tone said to include 'a place's ambiance, its physical fabric and character' along with 'the attitude of its people, its heritage, and narratives', in short, a destination's 'sense of place'.

Anholt (2009:30) utilises the term 'sense of place' to denote those aspects that make a location distinctive and memorable and thus communicate its personality. For Anholt, this sense of place is derived from a variety of factors which are considered the 'DNA of a place' and which primarily consist of the place (the physical and cultural environment), the products with which the place is associated, and the people. For Campelo, et al., (2014), sense of place is the interaction of the tangible physical aspects, such as geographic location and physical landscape, as well as the less tangible though equally significant elements of the social and cultural capital that embody and represent the appeal of the destination. What is more, they propose that destinationbranding strategies should begin by understanding what constitutes this sense of place. To this end, several destinations have developed 'sense of place toolkits' so that local businesses can promote a consistent place brand which communicates the sense of place and the unique features therein. The ultimate aim is to communicate this difference as a source of potential competitive advantage to visitors. A toolkit may identify unique (local) selling points, information-based resources to share with visitors, branding guidelines and resources, visitor-based research, recommendations for improving the visitor experience and various other forms of information. In developing a sense of place toolkit, destinations must agree upon and clarify a sense of place which makes their locales distinctive and different from others. Potentially there are a few ways in which this can be achieved, some of which are discussed in this case based view of sense of place toolkits.

It remains to be seen if a sense of place toolkit is an element of destination marketing, or alternatively, a means of interpretation for protected landscapes, with a view to identifying and subsequently preserving local distinctiveness (Sibbald, 2012). In addition, place is a deceptively complex subject; considered a constantly evolving process rather than fixed. Thus, the aim of this paper is to explore how practitioners identify a workable idea of sense of place through toolkit workshops, as well as to offer a critique of these developments from an academic standpoint. Yet these two aims are in fact two sides of the same coin, the central issue is that place and sense of place are potentially challenging concepts to work with. Firstly, the paper will outline what is meant by both 'place' and 'sense of place'. 


\section{LITERATURE REVIEW}

\section{Issues of Place}

In the most basic terms place can be can be defined as space which has been ascribed meaning: place $=$ space + meaning. This would see space defined in opposition to place as amorphous and not having meaning as suggested by Relph (1976) and the Humanistic Geographers of the 1970s and 1980s. This body of work places 'human consciousness, feeling, thoughts and emotions at the centre of geographical thinking' (Cresswell, 2015:109). The work of Tuan had a particular impact on ideas of place; he considered place from the point of view of experience, which he views as an umbrella term for the various modes through which a person constructs a reality. Tuan's (1974) concept of Topophilia represents the love of a place, but discussions on place are just as likely to be negative or reflect concerns regarding the modern world. Arguably, observations regarding the growth of placelessness (Relph, 1976) or non-places (Augé, 1995) help explain the desire of many tourists for distinctive places and authentic experiences. Ideas that lie at the heart of much of the academic discourse within tourism studies (MacCannell, 1976, Sharpley, 2003).

In contrast with much of the Humanistic movement, contemporary Human Geography's reading of place is likely to be complex and ideographic. Massey (1997) suggested that places are relational, with multiple identities and represent a set of on-going processes. Human Geographers now tend to consider place(s) to be diverse, constantly becoming, contested and above all constructed (Cresswell, 2015). Furthermore, rather than mass tourism and globalisation stripping areas of their sense of place, more complex processes may be at work which might constitute the evolution of a new sense of place, which reflects modern-day mobilities and a process of hybridization (Lippard, 1997). This article fully acknowledges but does not focus on these broader developments.

Table 1. The levels at which place is approached (Adapted from Cresswell, 2015:56)

Level One:

A descriptive approach to place
Concerned with the distinctiveness and particularity of places; The world is a set of places, each of which can be studied as a unique and particular entity.

Level Two: Considers the particularity of place, but as instances of more general underlying A social constructionist social processes; Emphasises the unique attributes of place. approach to place

Level Three: Unconcerned with the unique attributes of particular places, or social forces A phenomenological involved in construction of place; Seeks to identify the essence of human approach to place $\quad$ existence as one that is necessarily and importantly 'in-place'; Less concerned with 'places' and more interested in 'Place'. 
In summarising the complex set of ideas relating to the study of place Cresswell (2015:55), identifies three levels at which the concept of place can be approached (See Table 1). For the specific purpose of this case study, it is advocated that sense of place relates most closely to level one of Cresswell's framework, given that the toolkits aim to understand the distinctiveness of a given place.

\section{Sense of Place and Tourism}

Place identity is forged in the interplay between a personal identity and topographical place (or space); perhaps most obviously demonstrated by how we identify ourselves with nations, regions, cities and our homes. When place identity becomes strong enough to be felt or experienced, then we often refer to the term sense of place (Jorgensen and Stedman, 2001). Furthermore, Geographers refer to sense of place as the subjective and emotional attachment people have to (a) place (Cresswell, 2015).

For the purposes of this paper, sense of place is defined as the fluid and multi-faceted way in which we know notable or memorable places through sensing, experiencing, and remembering a geographical location and its features. It is, therefore, a combination of our interaction with a physical environment and the meanings that we (as individuals and a society) bestow upon it, at the time or subsequently.

Increasingly, sense of place is being considered in the context of tourism and leisure studies, though Kyle and Chick (2007) contend that discussion of human-place relationships remains limited in comparison with other disciplines. Stedman et al., (2004) examines place meanings and attachment within National Parks in the United States, whilst Kianicka, et al., (2006) compare the sense of place of tourists and locals in the Swiss Alps, suggesting both groups feel sense of place deeply with landscape as key. Jarratt (2015) proposes a touristic sense of place for traditional British coastal resorts that he refers to as seasideness; here the seascape is key. Ettenger (2015) identifies how the sense of place of cultural tourists to Maine is much influenced by what they have seen or heard beforehand. More recently, Rout, Adjizian, and Auger (2016) explore the symbolism of place for touring skiers in Quebec.

More broadly, sense of place has been compared with the eco-musée concept, which seeks to conserve and interpret the 'cultural touchstones' within a defined geographical area (Bowles, Green and Graham, 2008). Originating in France in the mid-1970s, there are now believed to be over 400 eco-musée world-wide, including Ukraine, Canada, Mexico, Taiwan and Japan (Davis, 2011). Whilst the eco-musée concept is arguably a wider conceptualisation than sense of place, in that it seeks to interpret and manage community heritage within a broader sustainable development philosophy, the emphasis on championing local distinctiveness demonstrates that sense of place principles hold universal value and appeal (Bowles, Green and Graham, 2008).

What becomes clear is that our understanding of sense of place can support destinations in facilitating visitor attachments to place. Certainly, destination image and reputation are best communicated to visitors through the emotions associated with a destinations tone; in effect, its sense of place (Campelo et al., 2014; Morgan et al., 2011). In addition, the more a destination can engage with visitors on an emotional level, as somewhere that can 
provide a fulfilling experience, then the greater the potential to attract and retain visitors. In short, to create this emotional link, destinations must tell a story that offers an insight into the place and people (Anholt, 2009).

\section{Introducing Sense of Place Toolkits}

The application of sense of place toolkits has largely been overlooked in the literature. One notable exception is the work of Haven-Tang and Jones (2006) who record the successes of 'Sense of Monmouthshire', in differentiating a destination and creating a unique visitor experience based on the attributes of this Welsh region. Specifically the food and drink offer, its cultural and built heritage, its local arts and crafts, as well as its natural assets and outdoor activities. Elsewhere, Hopley and Mahony (2011) discuss the potential of a sense of place toolkit for marketing the Forest of Bowland Area of Outstanding Natural Beauty (AONB), though from more a practitioner than an academic standpoint. Both the Monmouthshire and Bowland toolkits are indicative of sense of place initiatives and as Table 2 confirms, local food, heritage, and culture, recreation opportunities, landscape features, and wildlife, are the main thematic focus of the toolkits that have been identified. It should be noted that whilst sense of place has been explored in many regions of the world, the toolkit to operationalise this would seem to be restricted, at present, to the UK and primarily to rural areas. Though, as will be outlined later, we advocate that the potential is more far-reaching.

The underpinning analysis for Table 2 also identifies that a sense of place toolkit can include the following:

- Place-related themes, key words, and images for promotional purposes

- Place specific facts, case-studies and further sources of information to share with visitors

- Research and recommendation on visitor perceptions and needs

- Branding guidelines/resources

- Contact and potential networking information

Local businesses can use such resources for promotion purposes but in a way which is cohesive, compatible and consistent with efforts by other businesses in that area. The hope is that efforts of promotion will contribute to and/or culminate in an over-arching sense of place featuring unique selling points, which may entice visitors and potentially shape their experience through interpretation and the promotion of attractions and activities. It would not help to be too prescriptive here, as a toolkit should, of course, be multi-faceted and different resources may be needed for different situations and places.

The toolkits in Table 2 take the form of downloadable documents and supporting web-based resources and represent a shared or similar design, which includes an overview of the destination. Whilst the majority of these are descriptive and factual, a smaller number of toolkits offer suggested itineraries and key attractions using the words of local stakeholders. Perhaps the best example is the Forest of Bowland toolkit, which signposts specific natural features and wildlife that visitors should be able to identify and enjoy across the seasons (Lancashire County Council, 2015).

Both the Clwydian Range AONB (2011) and South Downs National Park (2013), have extended their toolkit resources to include suggested narratives and wording as well as downloadable images that may be used in the 
print and web communications of rural business stakeholders. In both instances, the sense of place toolkits appear to be extensions of the regional marketing and communication strategy. Furthermore, the Clwydian Range toolkit has been intentionally designed to sit alongside branding guidelines.

Table 2. A review of sense of place toolkits

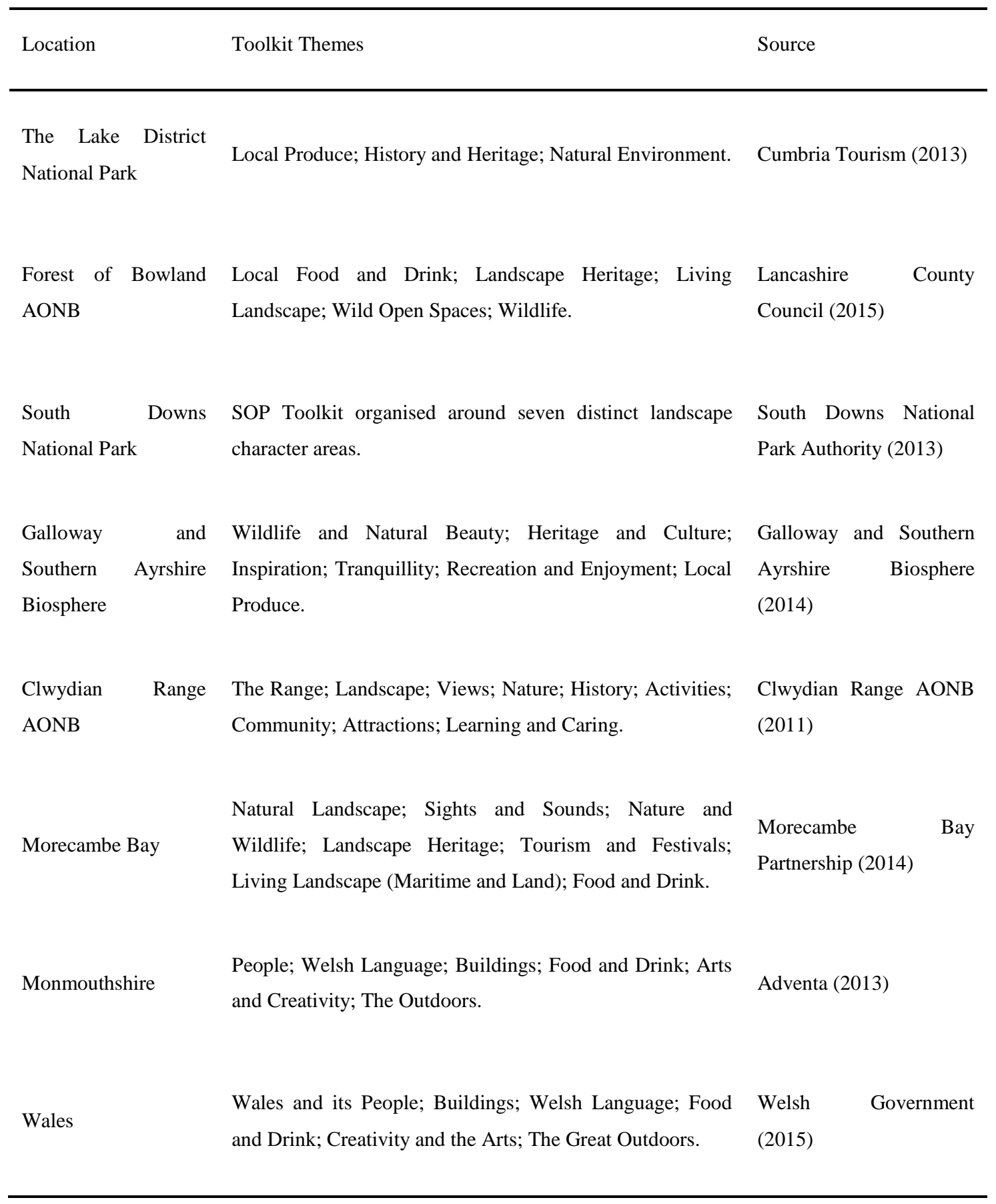

The emphasis on marketing and branding is less obvious in other toolkits. For the Wales, Lake District and Monmouthshire toolkits, the emphasis would appear to be on the provision of online resources that will allow businesses to understand, and in turn communicate the specific aspects of a place, whether this be the area's natural environment, food offer or rich culture and heritage (Adventa, 2013, Cumbria Tourism, 2013, Welsh Government, 2015). Undoubtedly, this will lead to more enhanced forms of outward communication, but for 
these destinations, explicit marketing, and branding language is not offered. Thus, these toolkits may be considered more as interpretation documents (Sibbald, 2012).

Broadly, each toolkit initiative places emphasis the uniqueness and distinctiveness of their location. Monmouthshire refers to the distinction between 'sense of place' and 'placelessness' and notes that visitors to the region have undoubtedly driven past supermarkets, retail parks, and fast-food outlets en-route and are thus now seeking the 'epitome of rurality', to include: heritage and culture, landscapes, people, food and language (Adventa, 2013:1). The Galloway and Southern Ayrshire Biosphere toolkit (2014:5) summarises this prevailing view quite succinctly, in describing sense of place as 'the term used to describe the emotions and experiences we associate with places'; for these toolkit authors, it is 'how places make us feel'.

Many of the toolkits reviewed also seek to communicate the benefits that sense of place can offer for the local visitor economy and its tourism stakeholders. For instance, Monmouthshire identifies that if visitors can connect with and develop an affinity for a place, then they will spend more time money at the destination, as well as generating repeat visits and sharing this feeling with friends (Adventa, 2013). For Galloway and Southern Ayrshire (2014:6), developing a sense of place is seen to benefit the destination in five distinct ways:

1. Improving the welcome and local knowledge of frontline tourism staff and business stakeholders

2. Adding value to local products and services, as well as helping to develop new products

3. Providing inspiration for education, interpretation and the creative arts

4. Bringing communities together and reconnecting people with their landscape

5. Generally strengthening the identity of the Galloway and Southern Ayrshire brand

As outlined earlier. It is evident that sense of place toolkits are predominantly rural and largely UK centric. However, it is arguably the case that it is the terminology or descriptor, that reflects a UK bias, given that sense of place itself is a universal concept. Indeed, earlier discussion of the eco-musée concept reveals that concerns around local and community distinctiveness are global. In Iceland, a 'local characteristics and assets toolkit' has been developed for tourism operators in the Snæfellsnes Peninsula Regional Park (Alta, 2012). A similar approach is adopted by the US Environmental Protection Agency (2017), through the 'local foods, local places toolkit' which helps communities identify what makes their places special and cherished and subsequently uses food and local distinctiveness to help communities achieve their place making goals. Moreover, the EPA suggests a series of community visioning and action planning workshops, with evident parallels to the toolkit development process advocated in the Morecambe case below. This process is echoed by the American Planning Association (APA), who recommend the use of masterplans and civic visioning to reinforce sense of place and celebrate community character (Soule et al., 2011). In considering the urban relevance, Adams et al. (2017) identify that sense of place principles are equally as relevant to cities, particularly in regard to building sustainable and ecologically aware communities. Indeed, the EPA and APA guidance noted above, does not distinguish between rural and urban contexts. Thus, the lessons of the case presented here should be seen to have wide applicability. 
To summarise, each of the sense of place and distinctiveness toolkit projects reviewed is the work of public and third sector partners, including DMOs, and has either been authored by teams of consultants or the partners themselves. Moreover, it is also clear from the toolkit documents, that many of the sense of place initiatives have been the recipients of public funding at both the regional and national level, including EU rural development funds. However, despite this, few of the toolkit projects reviewed share their specific methodologies or offer insights into how the elements of place and local distinctiveness have been determined. As such, the case study that now follows, offers useful insights for destination managers and stakeholders who are engaged in similar initiatives.

\section{METHOD}

This research follows a single case study approach to examine the development and implementation of a sense of place toolkit in a rural context. Traditionally, the case study method has been advocated as an appropriate method to allow for a deep understanding of a situation (Yin, 2012). Moreover, the case method is considered a valuable methodological tool in tourism research (Hyde et al., 2012). As is outlined below, the Morecambe Bay Toolkit was selected as it represents a rare opportunity to explore the practicalities and challenges of engaging stakeholders in the process of identifying key elements of sense of place. Potentially this case study offers insights for destinations engaged in similar initiatives.

Unusually perhaps, the best way to understand how this research came about is to consider the role of the authors. The first two authors of this article are academics with an interest in sense of place and rural tourism; they were invited to engage with the workshops and toolkit development processes detailed in this paper. The facilitators of these workshops, and toolkit authors, are experienced consultants who were employed by the Royal Society for the Protection of Birds (or RSBP) and Nurture Lakeland. They were to become the third and fourth authors of this journal article based upon a shared interest in the subject area and a desire reflect upon and share best practice. The two principal authors, the academics, conducted in-depth semi-structured interviews with these practitioners. These recorded interviews involved all four authors and were reflective and discursive in nature; the practitioners shared the workshop rationale, methods and offered a critical appraisal. The subsequent writing process was also a part of this reflective process and the involvement of the expert practitioners ensured accuracy. So, the methodology thus far can be described as intra-author analysis. The two academics then authored the discussion section, thereby offering a critique of sense of place workshops based on workshop attendance and participant observation, document analysis of key materials shared by the practitioners and the semi-structured interviews. The triangulation of these methods is illustrated in Figure 1.

Advantages of participant-observation include a directness / lack of dependence on recall and it takes place in a 'natural setting' allowing the context to be noted or experienced (Gratton and Jones 2010). In other words, details are detected which might otherwise be missed. For example, in this case 'how' the workshops were run, with the social / communication skills of the facilitators - this was something which was explored in the subsequent interviews. Disadvantages include the potential misunderstanding of the phenomena, but this was overcome by using it in conjunction with interviewing, as suggested by Gratton and Jones (2010: 181). Another 
potential disadvantage is the effect of the observer on the subject(s), but in this instance the events and groups were not well established, indeed introductions were necessary for the sake of several attendees. It was felt by the authors this this effect was not significant in this case but course one can never be entirely sure.

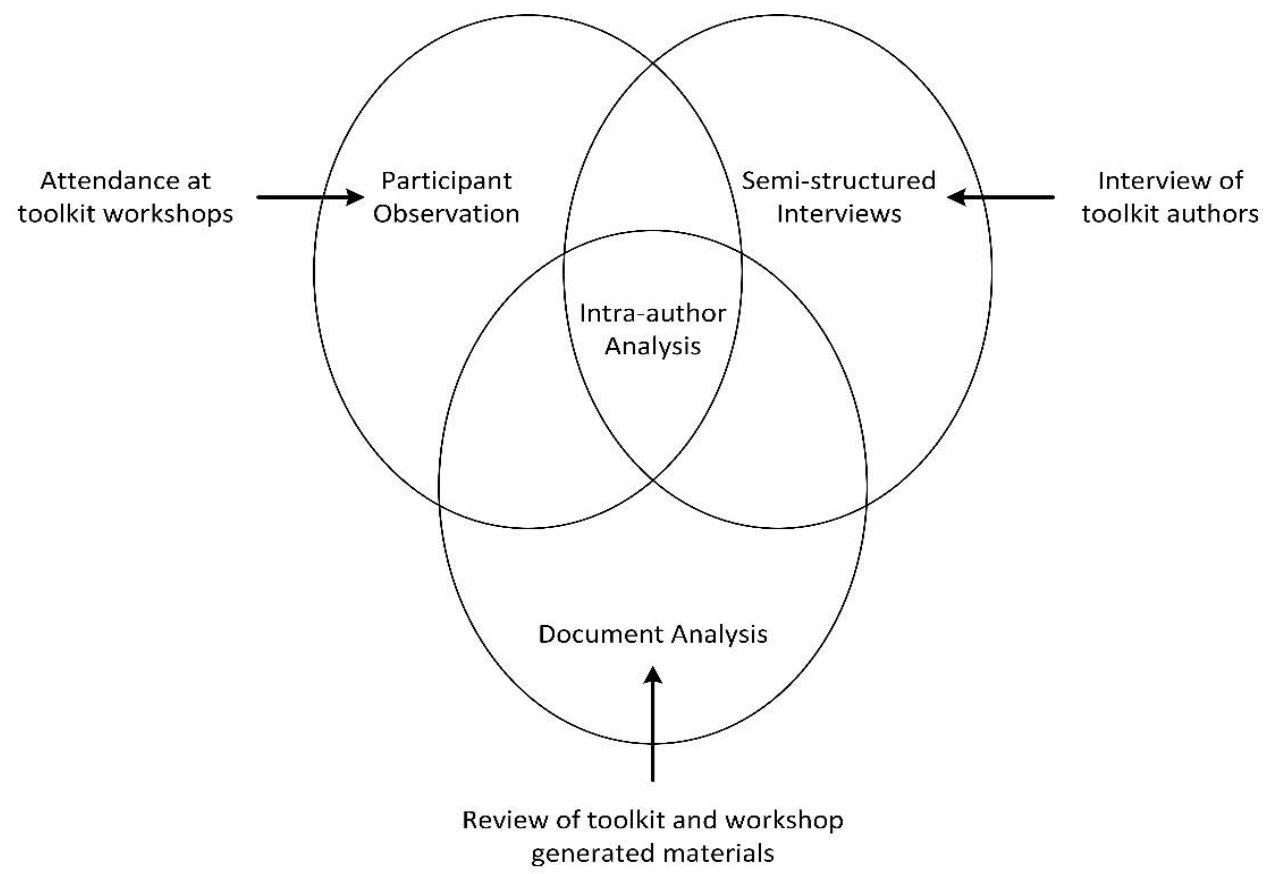

Figure 1. Triangulation of the case study (Adapted from, Woodside, 2010)

This study was not only selected for pragmatic reasons, but also adopted a pragmatic approach in employing all available resources - notably, this includes access to and full cooperation from the authors of the sense of place toolkit themselves, thereby offering a unique insight. This research has not endeavored to tie itself to any methodological approach although this case study is clearly qualitative. This study employed what Dingwall (1997: 52) playfully refers to as 'the only two basic methods of social research', that is 'asking questions' and 'hanging out'. The authors are unaware of any other study that considers the use of sense of place workshops/toolkits. This study is also unique because of the absence of academic attention to the geographical area concerned, which is introduced in the following section.

\section{THE CASE}

\section{Morecambe Bay, North West England, UK}

Located in the North West of England, Morecambe Bay is Britain's largest intertidal area. Despite existing as a geographic entity, the bay has no unified administration, straddling the counties of Cumbria and Lancashire (see Figure 2). The bay is strongly influenced by towns with differing industrial bases: Barrow-in-Furness (an industrial town associated with shipbuilding), Ulverston (a market town), Grange-over-Sands (a small resort and retirement centre), Morecambe (a resort which is going through regeneration), Heysham (a working port and the 
site of a nuclear power station) and Fleetwood (which is primarily associated with the fishing industry but still depends on the visitor economy).

The bay dominates local history, the natural environment, landscape and, arguably, offers the most distinctive element to the visitor experience. The bay is not only a vista but provides specific elements of the experience such as beaches, wildlife/nature reserves, fishing, local produce and even the renowned cross-bay walks with The Queens Guide to the Sands. Thus, Morecambe Bay is a famously dynamic natural environment, which is distinct and seems likely to inform the tourist experience through the products, activities, and vistas it offers. Indeed, the regional tourist board responsible for the southern part of Morecambe Bay describe it as 'a place with unique wildlife and habitats and a great place for outdoor adventures'. Their website promotes the destination in terms of walking, cycling and 'wildlife adventures', boasting of 'nature's amphitheatre' (Visit Lancashire, 2017). Evidently, the bay offers the potential of a clear destination identity for this area in terms of tourism marketing.

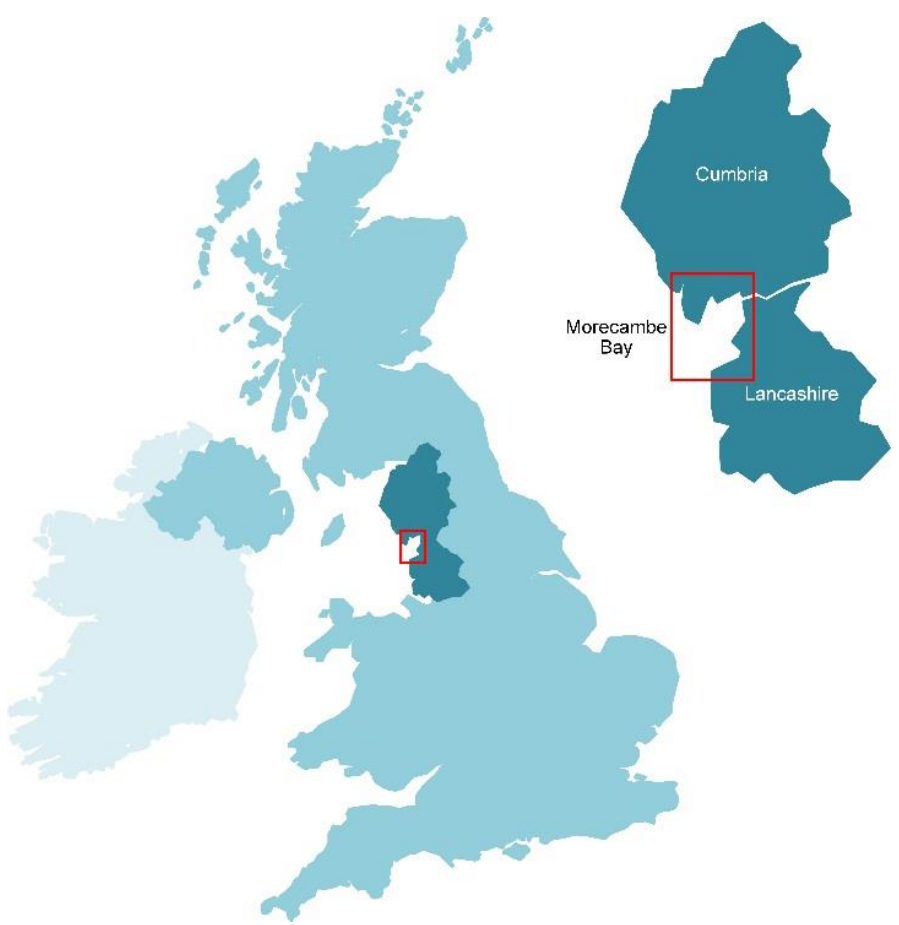

Figure 2. Case study area (Morecambe Bay, UK)

\section{The Morecambe Bay Sense of Place Toolkit}

The bay itself is well known, however, the different sides of this horseshoe-shaped bay were not promoted as a single destination until the recent work of the two organisations who co-sponsored the sense of place toolkits. These were the Morecambe Bay Partnership and The Morecambe Bay Local Nature Partnership. The Morecambe Bay Local Nature Partnership focusses on improving quality of the natural environment and access; the RSPB (a key stakeholder in this partnership) was the first to commit funds to the toolkit. The Morecambe Bay Partnership also aims to bring benefits to local heritage and the environment; it has been associated with successful funding bids and the establishment of The Bay Cycleway. Both organizations aim to engage local 
communities, local businesses, and visitors; one of the challenges facing this both organizations was the clarification of place identity (especially the distinctive elements of place) in a way which can be communicated to visitors through local stakeholders. In general, there are potential tensions between existing place identity and place making, which is how the work of the Morecambe Bay Partnership might be viewed. It is important to ensure that stakeholders engage in this process, to minimise any such tension (Chalip and Costa, 2005). Herein lies one of the main strengths of the sense of place toolkits and workshops, they accommodate the views of local businesspeople and residents.

As discussed earlier, a sense of place toolkit can include: 1) place-related key words and images which businesses can employ for promotional purposes, 2) place specific facts and sources of information for interpretation and promotion, 3) research and recommendations regarding markets, visitor perceptions, and needs, or 4) a proxy for branding guidelines. Local businesses can use such resources for promotion purposes but in a way that is cohesive, compatible and consistent with promotion from other businesses in the area. The intention being, that efforts of promotion will contribute to and/or culminate in an over-arching sense of place featuring unique selling points, which may entice visitors and potentially shape their experience through interpretation and the promotion of attractions and activities. It would not help to be too prescriptive here, as any toolkit should be multi-faceted and different resources may be needed for different situations and places. With respect to the Morecambe Bay toolkit, "the toolkit helps to celebrate the area's uniqueness and provide... [businesses] with information to develop visitors' perceptions of Morecambe Bay as a destination" (Morecambe Bay Partnership, 2014:1).

The need for a sense of place toolkit and visitor itineraries was expressed when the Morecambe Bay Partnership surveyed local visitor economy businesses. Respondents highlighted the need to improve visitor information and destination marketing, but also to provide opportunities for networking and fact-finding. Furthermore, the partnership's own research with visitors identified that $85 \%$ of visitors would like to explore the bay area using self-guided walking and cycling itineraries (Morecambe Bay Partnership, 2014). Generation of content to meet this need would be a challenge, as the area had not had its own interpretation before, nor been presented to visitors as one destination entity. A series of 'sense of place events' were thus developed to bring destination stakeholders together to achieve these aims.

The workshops specific aim was to establish the natural and cultural identity of Morecambe Bay and identify the key places where visitors can experience the best of the bay. This research was then incorporated into a sense of place toolkit for businesses, as well as self-guided walking and cycling itineraries for visitors (see, Morecambe Bay Local Nature Partnership, 2014). The workshops aimed to capture the place identity as experienced by destination stakeholders. The facilitators aimed to capture various associations with place including memories, myths, key words, artifacts, and perceptions more generally. Linking to this, the facilitators also wanted to know of places where the stakeholders may engage in various types of leisure activities from walking and experiencing nature, to eating and drinking. 


\section{Sense of Place: Workshop Structure}

A series of workshops were conducted at three locations around the bay - Condor Green, Ulverston, and Silverdale. In total, there were 42 attendees across the three workshops; each participated in the five activities outlined below:

Activity 1 - Visitor information

Groups of stakeholders were invited to brainstorm, and feedback based on the following three questions:

1. What information do you provide now?

2. What would you like to provide?

3. What do you need to provide this information?

Activity 2 - Identity

Groups were asked to spend time writing down words or phrases associated with four aspects of The Bay experience, before feeding back their favourites. The four aspects were:

1. Wildlife and Nature

2. Landscape and Views

3. Culture and Heritage

4. Food and Drink

\section{Activity 3 - Hidden Asset Survey}

OS maps of the Bay area were laid out and individuals were asked to indicate points of interest or favourite places and provide details on an 'asset sheet'. Stakeholders were encouraged to identify places of personal significance as well as points of more obvious potential touristic interest. This information was later collated for the 'Seldom Seen Maps Project' led by a local artist, and which were later made available for sale (see, Art Gene, 2016).

\section{Activity 4 - Vision}

Stakeholders were asked to consider where they would like the bay to be, in terms of tourism, in the future. More specifically, they were asked to fill out a blank postcard completing the sentence, "In 10 years, Morecambe Bay is a great place to be because..." This activity had been sent out to attendees by earlier email to allow time for a more considered answer.

\section{Activity 5 - Postcards}

Postcards, with questions about places on the back, were placed around the room. Individual stakeholders were asked to choose a postcard, complete it and stick it on the wall as if sending one from a holiday in Morecambe Bay. The questions on the back of the postcards were:

1. Where do you love to explore and what makes it so special to you?

2. What are your favourite memories of a day out around Morecambe Bay? 


\section{Workshop Outcomes}

In the first activity, attendees were asked: "What visitor information would you like to provide?" The responses to this question were incorporated into the itineraries and toolkit where possible, to ensure that the product would be relevant to businesses. Responses indicated the importance of business and marketing advice, sharing information / brand identity across Cumbria and Lancashire, online presence, days out itineraries, up to date and seasonal information (nature tourism and events), better images / image bank, better signage, access to walks, better travel information and links, including sustainable options such as bike hire. However, the most significant outcomes of the workshop relate to Morecambe Bay's sense of place.

At the heart of the workshops lay the sense of place activities. Workshop activity 2 led to the identification of several themes and sub-themes and comprised of 334 descriptions relating to the distinctiveness of Morecambe Bay. Interestingly, these confirmed and very closely matched the findings of the visioning exercise (activity 4). Culture and heritage attracted 73 comments, making it the third most significant theme. Here, history, fishing / maritime heritage, tourism heritage, arts and crafts and the vintage movement were key. Food and drink was considered highly significant. Critically, two additional points were raised. Namely, the provenance of food and linking food to experience of place, such as picking damsons in an orchard, or eating fish and chips on the beach.

Nature and wildlife was also identified as very important to the identity of Morecambe Bay, ranking second as a collective theme, with 97 comments. Descriptions from attendees related to the "impressive" national and international importance of Morecambe Bay for nature, both for individual species and as a broad habitat. It was stressed by participants that this should be highlighted through interpretation.

However, with 134 mentions, attendees commented on the theme of landscape (including seascape) the most. Thus, this theme and the process to identify it are considered a little more carefully here. The facilitators grouped the words used to describe the landscape and from this process, three main groups emerged: 1) drama/beauty, 2) vastness and 3) the spiritual/restorative. Apparently, the space created by the beautiful and open vistas engenders feelings of "spirituality" and wellbeing. The words used to describe landscape elements most often are summarised in Table 3.

Other descriptions of landscape included "diverse" and "dynamic". The attendees stressed that the views of the bay are never the same; one attendee noted, "The seascape and skyscape are constantly changing to create an infinite number of views". Sunrises and sunsets were often referred to, and when asked what makes them special, many attendees referred to the "colours" of the landscape. This is also linked to the dynamic nature of the clouds and tides. The attendees commented that when promoting the destination to visitors, a range of highquality images should be available to demonstrate this variety. It was also observed that landscape might also appeal specifically to photographers and artists as well as those interested in the countryside and nature. 
Table 3. Words used to describe the landscape and views

\begin{tabular}{ccc}
\hline DRAMA & VAST & SPIRITUAL \\
\hline Beautiful & Expanse & Escape \\
Dramatic & Open & Rest \\
Amazing & Space & Relax \\
Sublime & Scale & Healing \\
Stunning & Big & Forget All Your Cares \\
Breathtaking Views & Massive & Liberating \\
& & Magical \\
& & Freedom \\
& & Mystery \\
\hline
\end{tabular}

The workshops highlighted a wide variety of places of interest, which may not have been identified otherwise. Using the Hidden Asset Survey and Postcards (Activities 3 and 5), attendees described places where the visitor may be able to experience the special qualities and characteristics of Morecambe Bay. Of these, 65 places were identified as offering the best views/landscape highlights, 84 places were linked to nature and wildlife and 98 places were linked to local culture and heritage. Subsequently, wildlife and local history experts were interviewed to confirm this information. Finally, existing visitor information, in printed literature and online, was consulted to ensure that no major asset was omitted.

\section{DISCUSSION}

\section{Benefits and rationale for sense of place}

Successful branding will match the attributes of a brand with the target audience; brand choices are lifestyle statements that involve a potentially emotional relationship between the consumer and the brand in question (Morgan et al., 2011). Relationship with places more generally, also involves an emotional relationship. The strength of this relationship will vary and can be very strongly felt, such as a typical relationship with 'home' (Cresswell, 2015). A sense of place provides the essential emotional elements of a successful destination brand. The series of workshops aimed to explore these connections between people and place, and present them in such way as to increase tourism to the area.

The toolkit development process used a range of techniques to facilitate a sense of place, which involved the use of images and postcards to facilitate personal experience and memories - these were considered especially effective. It was also important to identify enthusiastic workshop facilitators, who could bring the stakeholders together and create an atmosphere which encourages the sharing of place-based ideas regarding identity. The organisers of the event also stressed the importance of relationships in this process. These had to be built up in the first place, through preliminary events. All of which helped establish a rapport and ensure cooperation at the toolkit events. Relationships and trust were developed between the facilitators and local business but also 
between different businesspeople who commented how useful the events were to them in terms of networking, especially in a macro environment where regional economic development agencies and other publicly funded tourism bodies have been cut back. In the interview, Dale observed that 'Lots of business members were so grateful to have something to bring them together, a talking point, something to share, they know what can be celebrated'; both interviewees stressed how the workshops had strengthened 'confidence' on the product/destination. One should not separate the development of such networks from the successful implementation of a place brand by businesses, who together with people they know and trust, can then share a common goal and vision and the confidence to promote their businesses alongside a unified place brand. This confidence, in the place and brand, was identified by the organisers as of vital importance and was effectively enabled through the soft skills of relationship building and rapport. In other words, it is not just a question of the process but who undertakes it and how they do it - in an open, welcoming, transparent and empathetic manner. After all, the aim of these events is to reveal sense of place, which is itself an emotional relationship which might not be discussed in a more formal business event. Wain also stressed the importance of the workshop(s) as a networking 'process' and pointed out that the collaborative nature of it ensured a level of 'buyin' or engagement with toolkit resources, which would otherwise be lacking if they had employed a more deskbased approach.

The organisers of the event were keenly aware of legacy; they hoped that their work would feed directly into a subsequent branding exercise, which was considered the next step. This has now happened with clear branding guidelines having been developed by the regional tourist board. The key messages communicated in this subsequent campaign are:

1. Inspire and Captivate - Big Views, Landscapes, and Natural Environment

2. Explore and Discover - Cultural Heritage

3. Engage - Outdoor Recreation (see, Marketing Lancashire, 2015).

A more coordinated approach would be desirable here, rather than branding seen as a separate process to a more interpretation focussed sense of place workshop. Resources that were influenced by the workshops, such as picture banks, websites and especially the online 'doorstep guides' (see, Morecambe Bay Nature Partnership, 2014) were considered important outcomes in themselves and something that would require maintenance in the future. The organisers also viewed the networking that came from the workshops as a valuable additional legacy, albeit a difficult one to assess.

As suggested above, there needs to be joined up thinking between the organisers of such events and destination marketers, something the organisers were aware of. In essence, was this event more about interpretation or marketing? The two need not entirely be separate but it is useful to clarify what the result of such a process should be, this obviously links not only to outcomes but the legacy of any such project. There may be a bias towards either interpretation or marketing and this is likely to be influenced by the background of the facilitators themselves and the priorities/culture of supporting organisations (Sibbald, 2012). The interviewees acknowledged that their background in conservation and sustainability meant that the emphasis was biased toward interpretation (of the natural environment especially), nevertheless they recognised the relevance of branding - Wain described the toolkit findings as, 'A layer of information that will help with branding'. 
Only one (quantitative) visitor survey informed the sense of place toolkit with no qualitative aspect for visitors these were used for local stakeholders alone. This is understandable in a climate of limited resources but it is desirable to employ a mixed method whenever possible in such case studies (Woodside, 2010). A qualitative tier of research is usually beneficial in exploring the nuanced way in which we know place; phenomenology would be well suited to exploring the subjective and emotional ways in which we experience and remember place (Jarratt, 2015). Research methods should consider potential differences between visitors and locals, which may be of significance in developing a toolkit.

One theme that was identified in the workshops, but perhaps warranted further exploration, was the restorative aspect of landscape and the natural environment. Nature tourism is perhaps an obvious way forward for rural areas, but the theme of restoration (wellness) widens the appeal. Indeed, sustainable tourism, nature tourism and the restoration associated with 'natural' environments overlap with one another. Escaping the pressure of modern day life and the restorative elements of the natural environment are the subjects of a growing body of literature (see Foley and Kistemann 2015 for a useful summary of this) and feed directly into the visitor experience and motivation (Jarratt 2015, Jarratt and Sharpley 2017, Jepson and Sharpley 2015). The glue that holds together this brand, with the various elements therein, could or should be restoration i.e. the focus should be more on how the various attractions make you feel, rather than the features of the place attractions themselves. Restoration has the advantage of linking to other concepts, which can be used to sell, not least slowing down and the slow movement, outdoor recreation and the original pull factor of the seaside resort.

More generally though, the idea of conveying feeling was not ignored in the subsequent branding guidelines, which use the terms 'Inspire' and 'Captivate' in relation to landscape (Marketing Lancashire, 2015). These paint a picture of an immediate reaction to place, rather than selling the benefit of place and tying it to wellness. That said, the Morecambe Bay branding exercise was certainly a positive development from the sense of place workshops, which clearly capture something of the area's genius loci. Furthermore, these terms could be considered as quite emotional in nature and marketing campaigns with emotional appeal are effective in influencing tourists' motivations (Min et al 2013). Prayag et al (2017) link emotional experiences, especially 'positive surprise' (which one might associate with impressive landscapes or wildlife encounters for example), and tourist satisfaction. Herein lies the potential for sense of place toolkits, which takes us beyond rural Britain to international tourism more generally.

\section{CONCLUSIONS AND RECOMMENDATIONS}

Sense of place toolkits offer clarification of commonly agreed features of interest that go some way to making up sense of place. The ultimate aim is to establish or strengthen place branding and so improve the regional visitor economy. An effective place brand is one that incorporates seemingly authentic and sustainable attributes that will appeal to a range of visitors into the future. An excellent example of research-based destination branding, which adopts the brand positioning of 'natural revival' can be seen in Wales. Based on the idea that people wanted to escape their stressful urban lives for short breaks in a seemingly natural and rural 
place, that is relatively convenient to get to for many people in England. Wales is communicated as unspoiled, traditional, green, authentic and beautiful - a place for spiritual and physical revival (see, Pride, 2015)..

However, human geographers remind us that places are fluid, so sense of place and a successful place brand will need to change over time. Geographers also agree that place is also contested, so an obvious question is 'whose sense of place is this?' One cannot assume that different age groups, socio-economic groups, and other groupings share a common vision of a place. Nevertheless, the techniques shared here can help the tourism industry highlight local points of interest and establish clear and appropriate marketing messages, which are less likely to be at odds with the local narrative than a more standardised or less 'rooted' approach. In so doing, sense of place toolkits offer the opportunity to clarify unique selling points and develop a more distinctive offering within an increasingly competitive visitor economy and increasingly mobile, connected and globalised world. They can help identify, communicate and ultimately sell the local, in other words, sell the emotional tone of a place. Yet ironically, many points of local culture and interest in Morecambe Bay are in danger of looking all too similar to the toolkit themes listed in Table 2. However, it is when one delves into local history, culture and the environment more deeply, that the real distinctiveness becomes apparent. The ingredients of local food, or the history of a building for instance. Destinations must ensure that the key brand images, the markers of place, and attractions are all suitably distinct, to gain consumer attention in the first place. Furthermore, one may well question if the local sense of place should always act as the keystone for place branding purposes. Perhaps, it is the tourist's sense of place, which may differ in some ways from that of the local, which deserves more attention. Some sense of place toolkits have accommodated this into their programmes and it would make an interesting area for future research to analyse the relative merits of these different approaches. In short, sense of place toolkits offer the potential to clarify interpretation, USPs and place branding strategies, but in practice, the tourist is sometimes notable in their absence in the proceedings except as end-consumers. There is no doubt that many visitors want to consume the local, but exactly which version of the local is perhaps another question. When one considers the fragmented nature of the modern tourism market, the challenge becomes to establish a sense of place that takes into the account the perception of tourists, on anything other than a superficial level.

\section{Lessons for Destinations}

With all this in mind, the authors offer some observations, which can be regarded as recommendations based upon what was observed during the workshop process and identified via the development of this case. Essentially, sense of place toolkits should:

- Clarify at an early stage if the objective is interpretation, branding or both.

- Assess how destination USPs translate into digestible brand messages and images: will they truly be distinct if other destinations are going through the same process?

- Incorporate the sense of place of as many destination stakeholders as possible (including businesses, residents and visitors).

- Identify the potential for the process to bring destination stakeholders together on broader destination relevant themes. 
- Consider a range of methods to explore what sense of place is, including qualitative techniques, which lend themselves to exploring experience, emotion, and perception, which might otherwise be missed.

- Acknowledge the emotional nature of our relationship to place and identify themes that relate to not only the place but also how that place makes you feel.

- Champion the emotional aspects and the benefits of place.

\section{REFERENCES}

Adams J, Greenwood D, Thomashow M, et al. (2017) Sense of Place. Available at: https://www.thenatureofcities.com/2016/05/26/sense-of-place/ (accessed 5 January 2018)

Adventa (2013) Sense of Place, Sense of Monmouthshire. Available at: https://businesswales.gov.wales/dmwales/sites/dmwales/files/Sense_of_Monmouthshire_ENG.pdf (accessed 17 March 2017).

Alta (2012) Tourism and Sense of Place. Available at: https://www.alta.is/tourism-and-sense-of-place (accessed 5 January 2018).

Anholt S (2009) 'Why National Image Matters', in UNWTO (ed.) Handbook on Destination Branding. Madrid: World Tourism Organization, pp. 8-17.

Anholt S (2010) Places: Identity, image and reputation. Basingstoke: Palgrave Macmillan.

Art Gene (2016) The Seldom Seen Series of Maps: Morecambe Bay. Available at: http://www.artgene.co.uk/news/seldom-seen-series-maps-morecambe-bay-now/ (accessed 18 June 2017).

Augé M (1995) Non-places: introduction to an anthropology of supermodernity. London: Verso.

Baker MJ and Cameron E (2008) Critical Success Factors in Destination Marketing. Tourism and Hospitality Research 8(2), 79-97.

Bowles J, Green S and Graham C (2008) Sense of Place Toolkit: Guidance for Heritage-based Rural Regeneration Projects. Available at: http://bowlesgreen.co.uk/wp-content/uploads/2010/05/TOOLKITFINAL.pdf (accessed 5th January 2018)

Campelo A, Aitken R, Thyne M, et al. (2014) 'Sense of place: The importance for destination branding', Journal of Travel Research, 53(2), 154-166.

Chalip L and Costa CA (2005) 'Sport Event Tourism and the Destination Brand: Towards a General Theory', Sport in Society, 8(2), 218-237.

Clwydian Range AONB (2011) Clwydian Range Sense of Place Toolkit. Available at: http://www.clwydianrangeaonb.org.uk/brand_central/senseofplacetoolkit/ (accessed 17 March 2017).

Cresswell T (2015) Place: an introduction. Chichester: Wiley-Blackwell.

Cumbria Tourism (2013) The Lake District, Cumbria Sense of Place Toolkit. Available at: http://www.cumbriatourism.org/marketing/sense-of-place.aspx (accessed 17 March 2017).

Davis P (2011) Ecomuseums: A Sense of Place. London: Continuum. 
Dingwall R (1997) ‘Accounts, Interviews and Observations’, in Miller G and Dingwall R (eds) Context and Method in Qualitative Research, London :Sage, 51-65.

Ettenger K (2015) 'The Other Maine Guides: How the Humanities Create Sense of Place and Enrich Tourism', Maine Policy Review, 24 (1), 73-79.

Galloway and Southern Ayrshire Biosphere (2014) Galloway and Southern Ayrshire Biosphere Sense of Place Toolkit. Available at: http://www.gsabiosphere.org.uk/wp-content/uploads/2014/11/Sense-of-

Place_Toolkit.pdf (accessed 17 March 2017).

Gratton C and Jones I (2010) Research Methods for Sport Studies. London: Routledge.

Foley R and Kistemann T (2015) 'Blue Space Geographies: Enabling health in place', Health and Place, 35, $157-165$.

Haven-Tang C and Jones E (2006) 'Using Local Food and Drink to Differentiate Tourism Destinations Through a Sense of Place: A Story from Wales-Dining at Monmouthshire's Great Table', Journal of Culinary Science \& Technology, 4(4), 69-86.

Hopley C and Mahony P (2011) Marketing Sense of Place in the Forest of Bowland, in Szymanski R (ed). Local Heritage, Global Context: Cultural Perspectives on Sense of Place. Abingdon: Routledge, pp. 33-52.

Hyde KF, Ryan C and Woodside G (2012) Field Guide to case study research in Tourism, Hospitality and Leisure (Advances in Culture, Tourism and Hospitality Research, Volume 6). Bingley: Emerald Group Publishing.

Jarratt D (2015) 'Sense of place at a British coastal resort: Exploring 'seasideness' in Morecambe', Tourism: An International Interdisciplinary Journal, 63(3), 351-363.

Jarratt D and Sharpley R (2017) 'Tourists at the seaside: exploring the spiritual dimension', Tourist Studies, 17(4), 349-368.

Jepson D and Sharpley R (2015) 'Exploring the Emotional Dimension of Rural Tourism Experiences', Journal of Sustainable Tourism, 23(8+9), 1157-1178.

Jorgensen BS and Stedman, RC (2001) 'Sense of place as an attitude: lakeshore owners attitudes toward their properties', Journal of Environmental Psychology Journal of Environmental Psychology, 21(3), 233248 .

Kianicka S, Buchecker M, Hunziker M et al. (2006) Locals' and tourists' sense of place: a case study of a Swiss alpine village. Mountain Research and Development, 26(1), 55-63.

Kotler P and Gertner D (2015) A place marketing and place branding perspective revisited. In: Morgan N, Pritchard A and Pride R (eds.) Destination brands: managing place reputation. Abingdon: Routledge, pp. 33-54.

Kyle G and Chick G (2007) 'The Social Construction of a Sense of Place', Leisure Sciences, 29(3), 209-225.

Lancashire County Council (2015) Forest of Bowland Sense of Place. Available at: http://www.forestofbowland.com/Sense-Place (accessed 17 March 2017). 
Lippard LR (1997) The lure of the local. New York, NY: New Press.

MacCannell D (1976) The tourist: a new theory of the leisure class. London: Macmillan.

Marketing Lancashire (2015) Morecambe Bay Brand. Available at:

http://www.marketinglancashire.com/visitor-economy/morecambe-bay-brand (accessed 18 June 2017).

Marzano G and Scott N (2009) 'Power in destination branding', Annals of Tourism Research, 36(2), $247-267$.

Massey D (1997) A Global Sense of Place. In: Barnes TJ and Gregory D (eds.) Reading human geography. London: Arnold, pp. 315-323.

Min K, Martin D, Jung J (2013) 'Designing Advertising Campaigns for Destinations with Mixed Images: Using Visitor Campaign Goal Messages to Motivate Visitors', Journal of Business Research 66 (6), 759-764.

Morecambe Bay Local Nature Partnership (2014) Nature on your doorstep guides. Available at: http://www.morecambebaynature.org.uk/node/78 (accessed 10 July 2017).

Morecambe Bay Partnership (2014) Morecambe bay Sense of Place Toolkit. Available at: http://www.morecambebaynature.org.uk/sites/default/files/uploads/Sense\%20of\%20Place\%20Toolkit \%20final.pdf (accessed 17 March 2017).

Morgan N, Pritchard A and Pride R (2011) Destination brands: managing place reputation. Abingdon: Routledge.

Pike S, Gentle J, Kelly L, et al. (2016) Tracking brand positioning for an emerging destination: 2003 to 2015. Tourism and Hospitality Research (online) DOI: 10.1177/1467358416646821.

Prayag G, Hosany S, Muskat B, and Del Chiappa G (2017) 'Understanding the Relationships between Tourists' Emotional Experiences, Perceived Overall Image, Satisfaction, and Intention to Recommend', Journal of Travel Research, 56 (1), 41-54.

Pride R (2015) The tone of voice challenge. In: Morgan N, Pritchard A and Pride R (eds) Destination brands: managing place reputation. Abingdon: Routledge, pp. 129-140.

Relph E (1976) Place and placelessness. London: Pion.

Roult R, Adjizian JM and Auger D (2016) 'Sense of Place in Tourism and Leisure: the Case of Touring Skiers in Quebec', Almatourism-Journal of Tourism, Culture and Territorial Development, 7 (13), 79-94.

Sharpley R (2003) Tourism, tourists and society. Huntingdon: ELM.

Sibbald S (2012) Sense of Place Toolkits - Marketing or Interpretation? [Message posted to the Association of Heritage interpretation discussion group]. Available at: https://www.linkedin.com/groups/SensePlace-toolkits-marketing-interpretation-4078892.S.97891284 (accessed 17 March 2017).

Soule J, Hodgson K and Beavers KA (2011) Community Character. Chicago: American Planning Association. Available at: https://planning-org-uploadedmedia.s3.amazonaws.com/legacy_resources/research/arts/briefingpapers/pdf/character.pdf (accessed 5 January 2018). 
Stedman R, Beckley T, Wallace S and Ambard M (2004) 'A picture and 1000 words: Using resident-employed photography to understand attachment to high amenity places'. Journal of Leisure Research, 36(4), 580-606.

South Downs National Park Authority (2013) South Downs National Park Sense of Place Toolkit. Available at: http://sopt.southdowns.gov.uk/ (accessed 17 March 2017).

Tuan Y-F (1974) Topophilia: a study of environmental perception, attitudes, and values. London: Prentice-Hall.

UNWTO (2009) Handbook on Destination Branding. Madrid: World Tourism Organization.

US EPA (2017) Local Foods, Local Places. Washington: US Environmental Protection Agency. Available at: https://www.epa.gov/sites/production/files/2017-10/documents/lflp_toolkit_508-compliant.pdf (accessed 5 January 2018)

Visit Lancashire (2017) Explore Morecambe Bay. Available at: http://www.visitlancashire.com/explore/morecambe-bay.

Welsh Government (2015) Sense of Place. Available at: https://business.wales.gov.uk/dmwales/about-sense-ofplace-2 (accessed 17 March 2017)

Woodside AG. (2010) Case Study Research: Theory, Methods, Practice. Bingley: Emerald Group Publishing. Yin R (2012) Applications of Case Study Research. London: SAGE. 


\section{Author Biographies}

\section{David Jarratt}

David Jarratt $(\mathrm{PhD})$ is a Senior Lecturer at The Lancashire School of Business and Enterprise, UCLan. His research interests revolve around the consumption of tourism and sense of place. He is currently exploring the relationship between wellness and coastal tourism.

\section{Chris Phelan}

Chris Phelan $(\mathrm{PhD})$ is a Senior Lecturer at Edge Hill University Business School. His research interests focus on small business management and entrepreneurship, with a particular focus on visitor economy enterprises in rural areas.

\section{Jenny Wain}

Jenny Wain is an independent consultant. Jenny is currently freelancing with Morecambe Bay Partnership to help shape its future ambitions and secure funding for new projects that celebrate and safeguard the assets around the Bay. She is a great advocate of landscape-scale delivery, nature tourism and environmental planning. She has spent the last 12 years working around Morecambe Bay and Cumbria with the RSBP and Cumbria County Council.

\section{Sarah Dale}

Sarah Dale joined Nurture Lakeland in 2013 after completing a PhD in Environmental Science at Lancaster University. Sarah has been involved with a number of responsible tourism campaigns including 'Dive Less See More' and 'Love Your Lakes'. 